\title{
Investigation of the relationship between TSH and serum lipids in patints with subclinical hypothyroidism and euthroid subjects
}

\section{Subklinik hipotiroidi hastalarında ve ötroid bireylerde TSH düzeyi ile serum lipid düzeyleri arasındaki ilişkinin araştırılması}

\author{
Halef Okan Dogan' ${ }^{1}$ Fatma Meriç Yılmaz ${ }^{2,3}$, Canan Topcuoğlu ${ }^{3}$ Dilek Berker ${ }^{4}$, \\ Yüksel Koca ${ }^{5}$
}

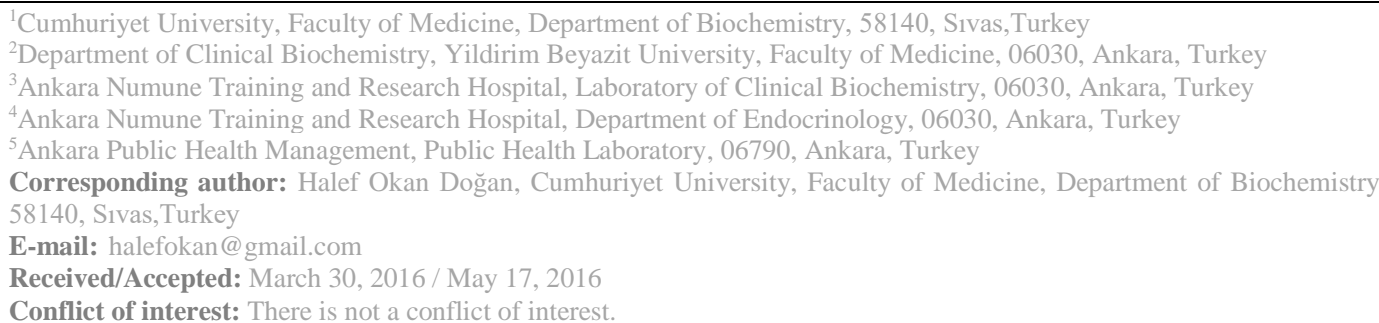

\section{SUMMARY}

Objective: Although the diagnosis and treatment of subclinical hypothyroidism (SH) primarily depend on the upper normal TSH serum concentration, there are not any well standardized reference limits to be used in the diagnosis and treatment of subclinical hypothyroidism. The aim of the study was to obtain data using serum lipid profile in order to optimize the target TSH levels especially for patients who have a high risk factor for atherosclerosis.

Method: A total of 213 patients with the diagnosis of SH and 178 euthyroid subjects were included in the study. Serum lipid parameters and the concentrations of thyrotropin (TSH), and free thyroxin $\mathrm{f}(\mathrm{T} 4)$ and free triiyodotironin $\mathrm{f}(\mathrm{T} 3)$ were recorded.

Results: Statistically significant difference was observed between patients and controls in terms of low density lipoprotein cholesterol (LDL-C), total cholesterol (TC), non-HDL-C and the ratio of TC/HDL-C. TSH level correlated significantly with LDL-C, TC, non-HDL-C and the ratio of TC/HDL-C in control and patient groups. According to LDL-C concentrations, different increased risk rate were observed in the presence of different TSH values.

Conclusions: We found positive correlation between TSH and atherogenic lipids as expected. Moreover, our findings showed that lower TSH concentrations which are still considered as normal, are also associated with increased lipid values. This might be important especially for patients who have a high risk for atherosclerosis and cardiovascular diseases. Thus, treatment of patients with above upper normal limit of TSH according to risk category might be helpful to reduce the atherogenic process.

Keywords: Subclinical hypothyroidism, lipid, TSH 
ÖZET

Amaç: Bu çalışmada subklinik hipotiroidi hastalarında ve ötroid bireylerde tiroid stimulan horman (TSH) düzeyi ile serum lipid düzeyleri arasındaki ilişki araştırılmıştır. Ayrıca serum lipid düzeyleri kullanılarak optimal serum TSH düzeyi belirlenmeye çalışılmıştır.

Yöntem: Calışmaya 213 subklinik hipotiroidi hastası ve 178 ötroid birey çalıșmaya dahil edildi. Çalışmaya dahil edilen bireylerin serum lipid (total kolesterol, LDL kolesterol, HDL kolesterol ve trigliserid), tirotropin (TSH), serbest tiroksin [s(T4)] ve serbest triyiodotironin [s(T4)] düzeyleri laboratuvar informasyon sistemindent aranarak kaydedildi.

Bulgular: Hasta ve ötroid kontrol grubu arasinda LDL-C, total kolesterol, nonHDL-C ve total kolesterol/HDL-C düzeyleri yönünden istatistiksel olarak anlamlı farklılık gözlendi. Hem kontrol hem de hasta grubundaTSH düzeyi ile LDL-C, total kolesterol, non-HDL-C ve total kolesterol/HDL-C düzeyi arasında pozitif korelasyon saptandı. Farklı LDL-C düzeyleri cutoff olarak alındığında TSH düzeyleri için farklı pozitif olasılık oranları ile karşıllaşıldı.

Sonuç: TSH düzeyindeki normal sınırlar içinde kalan artışlarda da bazı lipid düzeylerinde artış saptandı. Bu durumun özellikle koroner kalp hastalığı için risk faktörüne sahip bireylerde önemli olabileceği düşünülmektedir.

Anahtar sözcükler: Subklinik hipotiroidizm, lipid, TSH

\section{INTRODUCTION}

Subclinical hypothyroidism $(\mathrm{SH})$ is defined as an elevated thyroid stimulating hormone (TSH) level with a normal free throxine $\mathrm{f}\left(\mathrm{T}_{4}\right)$ level. ${ }^{1}$ The population prevalence of the $\mathrm{SH}$ is around \%5-10. ${ }^{2}$ In addition to progression to overt hypothyroidism, different adverse effects such as hypercholesterolemia, coronary artery disease can be seen in patients with $\mathrm{SH}^{3,4}$ However the detailed mechanism about the correlation between thyroid function and serum lipid profiles remains unclear ${ }^{5}$, linear positive correlation has been reported between TSH and serum cholesterol concentrations that are associated with an increase in morbidity and mortality due to coronary heart disease. ${ }^{6,7}$ Atherogenic index of plasma (AIP), non-HDL-C and the ratio of total cholesterol to HDL-C (TC/HDL-C) are calculated parameters that are defined as useful tools in individuals who have different cardiovascular risk factors. ${ }^{8}$ But there is lack of studies that evaluate the change of these calculated parameters in patients with $\mathrm{SH}$.

Subclinical hypothyroidism has few or no symptoms and thus diagnosis and treatment is made by laboratory tests such as TSH and f(T4). ${ }^{9}$ Therefore the discrimination between a normal and an elevated TSH concentration is important. Although the diagnosis and treatment of
SH primarily depend on the upper normal TSH serum concentration, there are not any well standardized clinical decision and upper reference limits to be used in the diagnosis and treatment of $\mathrm{SH}$ and there is a variation in the reference intervals between laboratories ${ }^{10-12}$. Thus, it is important that the clinical decision limit or upper reference limit for TSH has to be defined.

The purpose of this study was to investigate the relationship between TSH and serum lipid concentrations in euthyroid individuals without known thyroid disease and patients with SH. Our hypothesis was that serum lipid concentrations could be used as alternative indicators for the adjustment of optimal TSH levels to be used during diagnosis and treatment. We believe that the work will furnish a baseline data in the provision of treatment and diagnosis of patients with $\mathrm{SH}$ and screening of healthy individuals.

\section{Study population}

This study was undertaken in Ankara Numune Training and Research Hospital with the approval of the local ethics committee. All procedures performed in studies involving human participants were in accordance with the ethical standards of the institutional and/or national research committee and with the 1964 Declaration Helsinki and its later amendments or comparable ethical 
standards. A total of 213 patients with the diagnosis of $\mathrm{SH}$ were included in the study. Patients with diabetes mellitus, liver disease, nephropathy taking drugs for any condition, malignancy, pregnancy and other chronic and endocrine disease were excluded from the study. The female/male ratio and mean age were 3.35 and $48.1 \pm 14.7$ years respectively in the patient group. Control group composed of 178 euthyroid healthy persons without known thyroid disease and other drug usage, infection history (vira lor bacterial) that may affect tyroid functions. In control group, the female/male ratio and mean age were 2.39 and $47.5 \pm 15.5$ yeras, respectively. Exclusion criteria for the control group were the same as patients. Overnight fasting blood samples were collected from all participants. Red top tube (Becton Dickinson, UK) was used for the analysis.

\section{Study Design}

To understand the effect of SH on serum lipids, we compared serum lipid concentrations between patients and controls and then in order to demonstrate the effect of TSH concentrations on serum lipids, the correlation between serum TSH and serum lipids were examined in patients and control groups. The clinical decision limit for TSH is defined as $2,5 \mu \mathrm{IU} / \mathrm{mL}$ by National Acedemiy of Clinical Biochemistry. ${ }^{13} \mathrm{In}$ order to understand the effect of this cut off value on serum lipid concentrations, control group was divided into two groups ( Group 1 [n: 60 (\%33.71)] and Group 2 [n: $118(\% 66.29)]$ ) according to TSH concentrations $(\leq 2.5 \mu \mathrm{IU} / \mathrm{mL}$ and $>$ $2.5 \mu \mathrm{IU} / \mathrm{mL}$ ) and their serum lipid concentrations were compared with each other. Different cut off values such as > $6 \mu \mathrm{IU} / \mathrm{mL}$ or $>10 \mu \mathrm{IU} / \mathrm{mL}$ for TSH have being used in patients with subclinic hypothyroidism to start the treatment. ${ }^{14,15}$ It is reported that patients with SH might be treated due to dyslipidemia. ${ }^{16}$ To determine the changes of serum lipids in different TSH values, patients were divided into three groups (group 1: 4$6 \mu \mathrm{IU} / \mathrm{mL}$, group 2: $6.1-10 \mu \mathrm{IU} / \mathrm{mL}$ and group $3 \geq 10 \mu \mathrm{IU} / \mathrm{mL}$ ) and their serum lipids were compared with each other. To determine the optimal TSH concentrations in terms of serum lipids, we gathered controls and patients in one group (n: 391) and then the change of LDL-C concentrations were examined in different TSH concentrations.

\section{METHOD}

\section{Laboratory analyses}

Serum concentrations of TSH, $\mathrm{f}\left(\mathrm{T}_{4}\right)$ and $\mathrm{f}\left(\mathrm{T}_{3}\right)$ were analysed at the hormone laboratory, Ankara Numune Education and Research Hospital using Beckman Coulter DXI 800 ${ }^{\circledR}$ Access Autoanalyser ( Fullerton, USA) HYPER sensitive (hTSH) kit [functional sensitivity was $0.001-0.002 \mu \mathrm{IU} / \mathrm{mL}$ and according to concentration total analytical variation ranged between $3.72-10.62 \%$ ], free T4 [according to concentration total analytical variation ranged between 5.05 - $9.20 \%$ ] and free T3 [according to concentration total analytical variation ranged between 5.3 - 10.4\%]. The laboratory reference range were 0.34 $4.25 \mu \mathrm{IU} / \mathrm{mL}$ for TSH, $2.5-3.9 \mathrm{pg} / \mathrm{mL}$ for free T3 and $0.61-1.12 \mathrm{ng} / \mathrm{dL}$ for $\mathrm{f}(\mathrm{T} 4)$.

Triglyceride (TG), total cholesterol (TC) and HDL-C was determined on a Beckman Coulter DXC 800 UniCel $^{\circledR}$ Autoanalyser (Fullerton, USA). The day-to day coefficients of variation were $3.0 \%$ for TC, HDL-C and TG. LDL-C was calculated using Friedewald Formula by subtracting the sum of HDL-C and the TG concentration divided by 5 from the total cholesterol level ${ }^{17}$. In persons who had a serum TG concentration of $>400$ $\mathrm{mg} / \mathrm{dL}$; LDL-C concentrations were determined by using enzymatic colorimetric method in Beckman Coulter DXC 800 UniCel ${ }^{\circledR} \quad$ Autoanalyser (Fullerton, USA). The AIP was calculated by $\log$ (TG/HDL-C). NonHDL-C was calculated subtracting the sum of HDL-C from total cholesterol. ${ }^{8}$

\section{Statistical analysis}

Shapiro-Wilk test was used to determine the distribution characteristics of variables. Mann-Whitney U, Kruskall- 
Wallis and student $t$ tests were used to compare differences of each variable between groups. Results were expressed as median $\left(25^{\text {th }}\right.$ and $75^{\text {th }}$ percentiles). $\mathrm{p}<0.05$ level was considered statistically significant. Spearman method was used to assess correlation between serum lipids and TSH in control and patient groups. ROC analysis was used to determine the changes of serum TSH concentrations in different cutoff values for LDL-C. Analyses were performed using SPSS 15.0 for Windows (SPSS, Chicago, Illinois, USA).

\section{RESULTS}

Results are summarized in Table 1-4. In patients, serum LDL-C $[P<0.001]$, nonHDL-C $[P<0.001]$, total cholesterol $[P$ $<0.001]$ and TC/HDL-C values $[P=$ 0.038 ] were significantly higher than control groups (Table 1). In control groups, statistically significant difference were found between subgroups in terms of serum LDL-C [ $P=0.017]$, non-HDL$\mathrm{C}[P=0.002], \mathrm{TC}[P=0.003]$ and the ratio of total cholesterol to HDL-C $[P=$ 0.029] values (Table 2). In patient subgroups, statistically significant difference wasfound between groups in terms of serum LDL-C, non- HDL-C, TC and TC/HDL-C values (Table 3). Table 4. shows the changes of TSH values in different cut off values for LDL-C.

A positive correlation was found between TSH and LDL-C [controls: $(P<0,001, \mathrm{r}$ $=0,370)$ and patients: $(P<0,001, \mathrm{r}=0$, 482)], TC [controls: $(P<0,001, \mathrm{r}=0,304)$ and patients $(P<0,001, \mathrm{r}=0,427)]$, TC/HDL-C [controls: $(P<0,001, \mathrm{r}=$ 0,304) and patients: $(P<0,001, \mathrm{r}=$ 0,432)], non-HDL-C [controls: $(P<$ $0,001, \mathrm{r}=0,348)$ and patients: $(P<0,001$, $\mathrm{r}=0,455)]$ but we had not found any correlation among TSH and TG, HDL-C and AIP.

Table 1. The comparison of serum lipid concentrations between control and patient groups

\begin{tabular}{lccc}
\hline & Control $(\mathbf{n}=\mathbf{1 7 8})$ & Patient $(\mathbf{n = 2 1 3})$ & $\boldsymbol{p}$ \\
\hline LDL-C (mg/dL) & $109.00(85.00-130.25)$ & $126.00(104.50-164.00)$ & $<0.001$ \\
HDL-C (mg/dL) & $45.00(38.00-52.00)$ & $41.00(35.00-48.00)$ & 0.524 \\
non-HDL-C (mg/dL) & $130.50(103.75-155.00)$ & $155.00(128.00-203.50)$ & $<0.001$ \\
Triglyceride (mg/dL) & $126.00(68.00-155.50)$ & $134.00(92.50-189.00)$ & 0.091 \\
Total cholesterol (mg/dL) & $177.50(150.75-196.00)$ & $195.00(176.00-243.00)$ & $<0.001$ \\
Total cholesterol/HDL-C & $4.09(3.28-5.20)$ & $4.9(4.02-6.28)$ & 0.038 \\
AIP & $0.22(0.15-0.35)$ & $0.24(0.19-0.40)$ & 0.134
\end{tabular}

Results are expressed as median $\left(25^{\text {th }}\right.$ and $75^{\text {th }}$ percentiles $)$ and $p$ : indicates the significance between control and patient groups. 
Table 2. The comparison of serum lipids in controls who had different TSH concentrations

\begin{tabular}{lccl}
\hline & TSH $\leq \mathbf{2 . 5} \boldsymbol{\mu I U} / \mathbf{m L}$ & TSH $>\mathbf{2 . 5} \boldsymbol{\mu I U} / \mathbf{m L}$ & $\boldsymbol{p}$ \\
\hline $\mathbf{n}(\%)$ & $60(\% 33.71)$ & $118(\% 66.29)$ & \\
Mean age \pm SD & $47.78 \pm 15.64$ & $47.48 \pm 15.50$ & 0.673 \\
$\mathbf{L D L}-\mathbf{C}(\mathbf{m g} / \mathbf{d L})$ & $103.00(83.00-130.00)$ & $124.00(109.25-137.50)$ & 0.017 \\
HDL-C (mg/dL) & $45.00(38.00-52.00)$ & $42.50(38.50-47.75)$ & 0.628 \\
Non HDL-C (mg/dL) & $127.50(101.75-154.25)$ & $147.50(139.25-155.75)$ & 0.002 \\
Triglyceride (mg/dL) & $114.50(68.75-149.25)$ & $123.00(55.75-189.75)$ & 0.461 \\
Total cholesterol (mg/dL) & $172.00(148.00-196.00)$ & $193.50(184.50-196.00)$ & 0.003 \\
Total cholesterol/HDL-C & $3.85(3.14-4.69)$ & $4.42(4.06-5.22)$ & 0.029 \\
AIP & $0.23(0.15-0.34)$ & $0.21(0.15-0.36)$ & 0.494 \\
\hline
\end{tabular}

Results are expressed as median $\left(25^{\text {th }}\right.$ and $75^{\text {th }}$ percentiles $)$ and $p$ : indicates the significance between control and patient groups.

Table 3. The comparison of serum lipids in patients who had different TSH concentrations

\begin{tabular}{|c|c|c|c|c|}
\hline & $\begin{array}{c}\text { TSH=4.3 - } \\
5.97(\mu \mathrm{IU} / \mathrm{mL})\end{array}$ & $\begin{array}{c}\text { TSH=6 - } \\
9.46(\mu \mathrm{IU} / \mathrm{mL})\end{array}$ & $\begin{array}{l}\text { TSH } \geq 10 \\
(\mu I U / m L)\end{array}$ & $p$ \\
\hline$n(\%)$ & $122(57.28 \%)$ & $59(27.70 \%)$ & $32(15.02 \%)$ & \\
\hline Mean age \pm SD & $48.81 \pm 15.06$ & $46.52 \pm 14.80$ & $48.40 \pm 14.93$ & .778 \\
\hline LDL-C (mg/dL) & $\begin{array}{c}117.85(95.00- \\
138.00)\end{array}$ & $\begin{array}{c}131.00(119.00- \\
164.00)\end{array}$ & $\begin{array}{c}155.50(148.50- \\
190.25)\end{array}$ & $<.001$ \\
\hline HDL-C (mg/dL) & $\begin{array}{l}41.15(35.00- \\
49.00)\end{array}$ & $\begin{array}{l}40.00(33.00- \\
44.00)\end{array}$ & $\begin{array}{l}42.00(35.00- \\
48.00)\end{array}$ & .336 \\
\hline $\begin{array}{l}\text { Non-HDL-C } \\
(\mathrm{mg} / \mathrm{dL})\end{array}$ & $\begin{array}{c}145.00(118.00- \\
172.50)\end{array}$ & $\begin{array}{c}159.00(141.00- \\
201.70)\end{array}$ & $\begin{array}{c}185.50(174.00- \\
222.00)\end{array}$ & $<.001$ \\
\hline $\begin{array}{l}\text { Triglyceride } \\
(\mathbf{m g} / \mathbf{d L})\end{array}$ & $\begin{array}{c}130.50(87.75- \\
181.25)\end{array}$ & $\begin{array}{l}140.00(96.00- \\
203.00)\end{array}$ & $\begin{array}{c}134.50(103.50- \\
204.00)\end{array}$ & .620 \\
\hline $\begin{array}{l}\text { Total cholesterol } \\
(\mathbf{m g} / \mathbf{d L})\end{array}$ & $\begin{array}{c}188.50(163.50- \\
212.50)\end{array}$ & $\begin{array}{l}198.00(180.00- \\
241.00)\end{array}$ & $\begin{array}{c}226.00(204.25- \\
261.00)\end{array}$ & $<.001$ \\
\hline $\begin{array}{l}\text { Total } \\
\text { cholesterol/HDL-C }\end{array}$ & $4.55(3.60-5.58)$ & $5.21(4.38-6.32)$ & $6.55(5.2-9.08)$ & $<.001$ \\
\hline AIP & $0.20(0.17-0.38)$ & $0.24(0.19-0.35)$ & $0.23(0.15-0.27)$ & .483 \\
\hline
\end{tabular}

Results are expressed as median $\left(25^{\text {th }}\right.$ and $75^{\text {th }}$ percentiles $)$ and $u p$ : indicates the significance between control and patient groups. 
Table 4. The changes of TSH values in different cutoff values for LDL-C

\begin{tabular}{lllll}
\hline LDL-C $(\mathbf{m g} / \mathbf{d L})$ & TSH $(\mu \mathrm{IU} / \mathbf{m L})$ & Specifity $(\%)$ & Sensitivity $(\%)$ & LR $(+)$ \\
\hline LDL-C $\geq \mathbf{1 0 0}$ & $>2.4 \mu \mathrm{IU} / \mathrm{mL}$ & 70.30 & 60.00 & 1.76 \\
LDL-C $\geq \mathbf{1 3 0}$ & $>4.56 \mu \mathrm{IU} / \mathrm{mL}$ & 66.67 & 65.99 & 1.96 \\
& & & & 2.62 \\
LDL-C $\geq \mathbf{1 6 0}$ & $>5.02 \mu \mathrm{IU} / \mathrm{mL}$ & 74.65 & 71.56 & 4.01 \\
LDL-C $\geq \mathbf{1 9 0}$ & $>5.74 \mu \mathrm{IU} / \mathrm{Ml}$ & 82.05 & 79.55 & \\
\hline
\end{tabular}

LR (+): positive likelihood ratio, Results are expressed with the $95 \%$ confidence interval

\section{DISCUSSION}

It is generally accepted that subclinic hypothyroidy (SH) associated with dyslipidemia may cause vascular endothelial dysfunction and this condition might accelerate the formation of atherosclerosis. ${ }^{18}$ In our study, serum LDL-C, TC, non-HDL-C and TC/HDL$\mathrm{C}$ concentrations were found higher in patients than controls. However, we did not find any differences between patients and controls in terms of triglycerides and HDL-C concentrations. Most studies have shown increased concentrations of total cholesterol and LDL-C related to SH. ${ }^{19,20}$ Our findings support the aformentioned studies. Case-control and cross-sectional studies have been performed on the association between $\mathrm{SH}$ and serum lipids. ${ }^{21-24}$ Results from these studies are different. The discrepancy between results may rely on the great heterogeneity of the study population, differences in cutoff value for TSH levels used to define $\mathrm{SH}$, selection criteria and differences of the disease duration.

AIP is calculated by using HDL-C and TG concentrations. ${ }^{8}$ In the study, due to we did not find any significant difference between patient and controls in terms of HDL-C and TG, it was thought that the AIP is not a reliable calculated marker for the prediction of future coroner heart disease in patients with $\mathrm{SH}$. We also found correlation between TSH and LDL-C, non HDL-C, TC and the ratio of TC/HDL-C in both patient nad control groups. On the other hand we did not find any correlation between TSH and
TG and HDL-C concentrations in both groups. Some researchers reported different results related to the correlation between serum TSH levels and TC, TG, LDL-C and HDL-C. ${ }^{7,25}$ In three metanalysis, it was concluded that thyroxine replacement treatment had no effect on TG and HDL-C concentrations. $^{26-28}$ Accordingly, we concluded that thyroid hormone levels had a significant impact on serum lipid concentrations except for TG and HDLC. However, broad participation cohort studies must be performed to obtain exact conclusion.

We found statistically significant difference in terms of LDL-C, non-HDL$\mathrm{C}$, TC the TC/HDL-C between groups who had different TSH levels in controls. The association between LDL-C and coronary heart disease is well established. ${ }^{29}$ ATP III uses LDL-C as the primary target for cholesterol lowering therapy and also LDL-C concentrations that are below the $100 \mathrm{mg} / \mathrm{mL}$ is described as a negative risk factor for coronary heart disease. ${ }^{30}$ In our study, we found that the persons who had TSH > $2.4 \mu \mathrm{IU} / \mathrm{mL}$ had 1.74 fold increased risk to have a LDL-C concentration of $\geq 100$ $\mathrm{mg} / \mathrm{dL}$. We also found that serum LDLC, TC, non-HDL-C and TC/non HDL-C were higher in euthyroid healthy subjects with TSH $>2.5 \mu \mathrm{IU} / \mathrm{mL}$ and the difference between groups was statistically significant. The clinical decision limit for TSH is defined as 2,5 $\mu \mathrm{IU} / \mathrm{mL}$ by National Acedemiy of Clinical Biochemistry. ${ }^{13}$ We believe that $2.5 \mu \mathrm{IU} / \mathrm{mL}$ is also used as the optimal 
TSH concentration to decrease the risk factors associated with dyslipidemia in patients with $\mathrm{SH}$.

LDL-C concentration between 100-129 $\mathrm{mg} / \mathrm{dL}$ is defined as near optimal and above optimal in the National Cholesterol Education Program Expert Panel, respectively. ${ }^{30}$ It was found that the individuals with $\mathrm{TSH}>4,56$ had 2 fold risk to encounter of LDL-C concentrations $\geq 130 \mathrm{mg} / \mathrm{dL}$. The 0.3 to $5.0 \mu \mathrm{IU} / \mathrm{mL}$ range is the reference interval used by most laboratories ${ }^{31}$ but a lower upper limit of TSH was recently suggested. ${ }^{32}$ In the study made by Jensen et al. ${ }^{33}$ the upper normal limit of TSH has been defined as $4.5 \mu \mathrm{IU} / \mathrm{mL}$. We believe that $4,56 \mu \mathrm{IU} / \mathrm{mL}$ might be used as an upper normal value for TSH in terms of serum LDL-C concentrations. But a number of factors such as ethnic or regional difference, physiological and pathophysiological conditions have to be studied in order to make a conclusion.

Although the current consensus is to treat patients who have a TSH value $>10$ $\mathrm{mU} / \mathrm{L}$ with levothyroxine, disagreement continues regarding the treatment of patients having a serum TSH level above the upper limit of the normal range. ${ }^{34}$ In the study statistically significant difference was found in terms of total cholesterol, LDL-C, non-HDL-C, and total cholesterol to HDL-C ratio among patients who had different TSH values. Optimal serum lipid concentration is different according to risk category defined in National Cholesterol Education Program Expert Panel. These findings might show that it has not been possible to define an exact clinical decision limit for TSH to start treatment for decreasing the effect of dyslipidemia. Accordingly, all subjects with TSH levels above the upper reference range might be treated with thyroxine according to risk category defined in the NCEP expert panel for serum lipids.

One of the limitation of the study was that all study populations include same ethnic group which could not be generalized to other ethnic groups. Also, we did not adjust our data for body mass index and conducted anthropometric analysis. Other limitations were the lack of data about the patients' insulin resistance, thyroid antibody status and cigarette smoking status.

In conclusion, we found postivie correlation between TSH and atherogenic lipids as expected. Additionally, our findings showed lower TSH concentrations which are still considered as normal, were also associated with increased lipid values in all study population. This might be important especially for patients who have a high risk for atherosclerosis and cardiovascular diseases. Thus, treatment of patients with above upper normal limit of TSH according to risk category might be helpful to reduce the atherogenic process. On the other hand, epidemiological studies with large group individuals are needed to optimize the $\mathrm{TSH}$ values to start the treatment

\section{REFERENCES}

1. Tseng FY, Lin WY, Lin CC, Lee LT, Li TC, Sung PK, Huang KC. Subclinical hypothyroidism is associated with increased risk for all-cause and cardiovascular mortality in adults. J Am Coll Cardiol 2012; 60: 730-7.

2. Hollowell JG, Staehling NW, Flanders WD, Hannon WH, Gunter EW, Spencer CA, Braverman LE. Serum TSH, T(4), and thyroid antibodies in the United States population (1988 to 1994): National Health and Nutrition Examination Survey (NHANES III). J Clin Endocrinol Metab 2002; 87: 489-99.

3. Biondi B. Should we treat all subjects with subclinical thyroid disease the same way? Eur J Endocrinol 2008; 159: 343-5.

4. Ochs N, Auer R, Bauer DC, Nanchen D, Gussekloo J, Cornuz J, Rodondi N.Meta-analysis: subclinical thyroid dysfunction and the risk for coronary heart disease 
and mortality. Ann Intern Med 2008; 148: 832-45.

5. Wanjia $X$, Chenggang W, Aihong W, Xiaomei Y, Jiajun Z, Chunxiao $\mathrm{Y}$, Jin $\mathrm{X}$, Yinglong $\mathrm{H}$, Ling $\mathrm{G}$. A high normal TSH level is associated with an atherogenic lipid profile in euthyroid non-smokers with newly diagnosed asymptomatic coronary heart disease. Lipids Health Dis 2012; 11: 44.

6. Cappola AR, Ladenson PW. Hypothyroidism and atherosclerosis. J Clin Endocrinol Metab 2003; 88: 2438-44.

7. Asvold BO, Vatten LJ, Nilsen TI, Bjoro $\mathrm{T}$. The association between TSH within the reference range and serum lipid concentrations in a population-based study. The HUNT Study. Eur J Endocrinol 2007; 156: 181-6.

8. Millan J, Pinto X, Munoz A, Zuniga M, Rubies-Prat J, Pallardo LF, Masana L, Mangas A, HernandezMijares A, Gonzalez-Santos P, Ascaso JF, Pedro-Botet J.Lipoprotein ratios: Physiological significance and clinical usefulness in cardiovascular prevention. Vasc Health Risk Manag 2009; 5: 757-65.

9. Gillet M. Subclinical Hypothyroidism: Subclinical Thyroid Disease: Scientific Review and Guidelines for Diagnosis and Management. JAMA 2004; 291: 228-38.

10. Dickey RA, Wartofsky L, Feld S. Optimal thyrotropin level: normal ranges and reference intervals are not equivalent. Thyroid 2005; 15 : 1035-9.

11. Sikaris K. Application of the Stockholm Hierarchy to Defining the Quality of Reference Intervals and Clinical Decision Limits. The Clinical Biochemist Reviews 2012; 33: 141-8.

12. Brabant G, Beck-Peccoz P, Jarzab B, Laurberg P, Orgiazzi J, Szabolcs I, Weetman AP, Wiersinga WM. Is there a need to redefine the upper normal limit of TSH? Eur J Endocrinol 2006; 154: 633-7.
13. Baloch Z, Carayon P, Conte-Devolx B, Demers LM, Feldt-Rasmussen U, Henry JF,LiVosli VA, Niccoli-Sire P, John R, Ruf J, Smyth PP, Spencer CA, Stockigt JR;Guidelines Committee, National Academy of Clinical Biochemistry. Laboratory medicine practice guidelines. Laboratory support for the diagnosis and monitoring of thyroid disease. Thyroid 2003; 13: 3-126.

14. Gharib H, Tuttle RM, Baskin HJ, Fish LH, et. al. Subclinical thyroid dysfunction: a joint statement on management from the American Association of Clinical Endocrinologists, the American Thyroid Association, and the Endocrine Society. J Clin Endocrinol Metab 2005; 90: 581-85.

15. Surks MI, Ortiz E, Daniels GH, Sawin CT, et.al. Subclinical thyroid disease: scientific review and guidelines for diagnosis and management. JAMA 2004; 291: 228-38.

16. Fatourechi V. Subclinical hypothyroidism: An update for primary care phsicians. Mayo Clin Proc 2009; 84: 65-71.

17. Friedewald WT, Levy RI, Fredrickson DS. Estimation of the concentration of low-density lipoprotein cholesterol in plasma, without use of the preparative ultracentrifuge. Clin Chem 1972; 18: 499-502.

18. Duntas LH, Mantzou E, Koutras DA. Circulating levels of oxidized low-density lipoprotein in overt and mild hypothyroidism. Thyroid 2002; 12: 1003-7.

19. Walsh JP, Bremner AP, Bulsara MK, O'Leary P, Leedman PJ, Feddema P, Michelangeli V. Subclinical thyroid dysfunction as a risk factor for cardiovascular disease. Arch Intern Med 2005; 165 : 2467-72.

20. Luboshitzky R, Herer P. Cardiovascular risk factors in middle-aged women with subclinical hypothyroidism. Neuro Endocrinol Lett 2004; 25: 262-6. 
21. Jung CH, Sung KC, Shin HS, Rhee EJ, Lee WY, Kim BS, Kang JH, Kim H, Kim SW,Lee MH, Park JR, Kim SW. Thyroid dysfunction and their relation to cardiovascular risk factors such as lipid profile, hsCRP, and waist hip ratio in Korea. Korean J Intern Med 2003; 18: 146-153.

22. Toruner F, Altinova AE, Karakoc A, Yetkin I, Ayvaz G, Cakir N, Arslan M. Risk factors for cardiovascular disease in patients with subclinical hypothyroidism. Adv Ther 2008; 25: 430-7.

23. Erdem TY, Ercan M, Ugurlu S, Balci H, Acbay O, Gundogdu S. Plasma viscosity,an early cardiovascular risk factor in women with subclinical hypothyroidism. Clin Hemorheol Microcirc 2008; 38 : 219-25.

24. Efstathiadou Z, Bitsis S, Milionis HJ, Kukuvitis A, Bairaktari ET, Elisaf MS, Tsatsoulis A. Lipid profile in subclinical hypothyroidism: is L-thyroxine substitution beneficial? Eur J Endocrinol 2001; 145: 705-10.

25. Lu L, Wang B, Shan Z, Jiang F, Teng X, Chen Y, Lai Y, Wang J, Xue H, Wang S,Li C, Liu H, Li N, Yu J, Shi L, Hou X, Xing Q, Bai X, Teng W. The correlation between thyrotropin and dyslipidemia in a population-based study. J Korean Med Sci 2011; 26: 243-9.

26. Ineck BA, Ng TM. Effects of subclinical hypothyroidism and its treatment on serum lipids. Ann Pharmacother 2003; 37: 725-30.

27. Danese MD, Ladenson PW, Meinert CL, Powe NR. Clinical review 115: effect of thyroxine therapy on serum lipoproteins in patients with mild thyroid failure: a quantitative review of the literature. J Clin Endocrinol Metab 2000; 85: 2993-3001.

28. Tanis BC, Westendorp GJ, Smelt HM. Effect of thyroid substitution on hypercholesterolaemia in patients with subclinical hypothyroidism: a reanalysis of intervention studies. Clin Endocrinol (Oxf) 1996; 44: 643-9.
29. Iqbal A, Jorde R, Figenschau Y. Serum lipid levels in relation to serum thyroid-stimulating hormone and the effect of thyroxine treatment on serum lipid levels in subjects with subclinical hypothyroidism: the Tromso Study. J Intern Med 2006; 260: 53-61.

30. Bishop ML, Fody EP, Schoeff LE (editors). Clinical chemistry techniques, principles, correlations. 6th ed. Philedelphia; Wolters Kluwer, Lippincott Williams \& Wilkins; 2010.

31. Dickey RA, Wartofsky L, Feld S. Optimal Thyrotropin Level: Normal Ranges and Reference Intervals Are Not Equivalent. Thyroid 2005; 15 : 1035-9.

32. Brabant G. New normal ranges for TSH: when to treat? Dtsch Med Woshenschr 2009; 134: 2510-3.

33. Jensen E, Hyltoft Petersen P, Blaabjerg O, Hansen PS, Brix TH, Kyvik KO,Hegedüs L. Establishment of a serum thyroid stimulating hormone (TSH) reference interval in healthy adults. The importance of environmental factors, including thyroid antibodies. Clin Chem Lab Med 2004; 42: 824-32.

34. Canaris GJ, Manowitz NR, Mayor G, Ridgway EC. The Colorado thyroid disease prevalence study. Arch Intern Med 2000; 160: 526-34. 